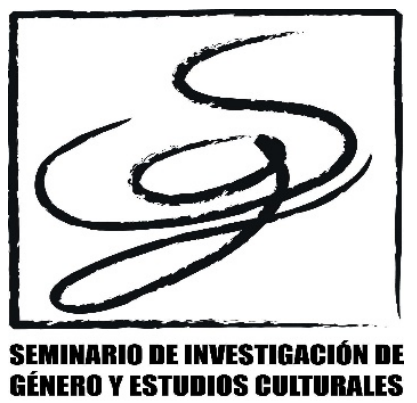

\title{
Pensando en pandemia con Donna Haraway. Reseña de Seguir con el problema: Generar parentesco en el Chthulceno. (2019) Bilbao, Consonni.
}

\author{
Barbara Yanina Dominguez \\ INDES (UNSE-CONICET) \\ barbi.y.dominguez@gmail.com
}

Fecha de recepción: 02/06/2021 Fecha de evaluación: 01/07/2021

Fecha de aceptación: 02/07/2021

\begin{abstract}
Vivimos tiempos desesperantes, récords de contagios y muertes por la covid-19, confinamientos y ruptura de lazos, pero también exposición intensificada. Pantallas y la costumbre de hablar sola en tu casa, de callar a tu perra, de sentir expuesta tu privacidad, pero con la certeza del deber cumplido. También cumplen su deber las personas que ahora llamamos 'trabajadores esenciales'1, están confinades al trabajo presencial. En las tierras, en los hospitales, en los supermercados 0 en las calles están aquellas personas que ganan poco y que junto con todo un mundo no-humano cargan con las tareas asignadas por el sistema para seguir perpetuando este tipo de vida en la tierra. Es que sucede que aún en estos tiempos al capitalismo le está yendo bien. Por eso, quienes todavía creemos que la emancipación es posible nos precipitamos a un abismo de emociones que nos deja a veces perdidas y otras veces derrotadas. Es por eso también, que para estos tiempos en los que la 'no vida' de los virus nos enfrenta de manera inevitable con el reflejo del sistema capitalista y todos los problemas que se han ido acumulando, de manera cada vez más acelerada, considero que la lectura de Donna Haraway puede ser un hilo que nos permita pensarnos aquí y ahora, con proyección a futuro y conciencia del pasado.
\end{abstract}

Donna Haraway escribió Seguir con el problema. Generar parentesco en el Chthulceno [Staying with the Trouble: Making Kin in the Chthulucene] en el 2016 y fue traducido al español en el 2019 por Helen Torres para la editorial Consonni. Los pensamientos de Haraway se sitúan en las intersecciones y por eso, cuesta tanto encontrar una única palabra

\footnotetext{
${ }^{1}$ Se usan comillas simples (' ') para las expresiones irónicas o coloquiales, se reserva el uso de comillas dobles (") para las citas.
} 
que pueda definir su producción. Esa capacidad de desplazarse entre disciplinas, que generalmente suelen ser muy específicas, posiblemente tenga relación con su formación académica y su activismo feminista. Por un lado, Haraway estudió para su formación de grado zoología y filosofía y se doctoró en biología, con una tesis sobre las funciones de la metáfora en la investigación en biología del desarrollo. Por otro lado, la autora se define a sí misma como feminista anti racista y anticolonialista por lo cual su producción se encuentra profundamente influenciada por la epistemología feminista, el feminismo negro, lésbico y chicano. Todo ello le permite situarse e inmediatamente criticar esa posición.

Entonces, aunque se la ha catalogado de ciberfeminista, postmoderna y/o posthumana, ella señala "soy una compostista", (Haraway, 2019: 157). Para Haraway nosotres somos compost, nuestra ontología es relacional y, a la vez, profundamente material. Particularmente pienso que 'compost' es una palabra que en muchos lugares del mundo 'hace sentido'. Muches de nosotres hemos aprendimos de nuestres abueles las técnicas del compostaje, y, muy probablemente, hemos también sido hechxs compost con otres seres. De modo que, en esa práctica, por una parte, devenimos con otres desde nuestros desechos y desperdicios, desde nuestras tristezas y heridas, desde nuestras alianzas y coaliciones, desde nuestros luchas y resistencias; y, por otra parte, heredamos y legamos formas de vivir y morir.

Podemos pensar la noción de compost desde SF, que son siglas en inglés usadas por la autora desde 1990. Ese año Haraway publicó el libro Primate Visions. Gender, Race, and Nature in the World of Modern Science [Visiones Primates. Género, raza y naturaleza en el mundo de la ciencia moderna, sin traducción al español] y recuperó el complejo campo indicado por el significador SF, de la antologista y crítica de ciencia ficción Judith Merril. A fines de 1960 había servido para indicar un orden narrativo emergente en el cual los límites entre ciencia ficción y fantasía se habían vuelto altamente permeables de maneras muy confusas. Haraway proponía incluir en ese campo las narrativas de los hechos científicos (scientific fact), con lo cual el significante SF se veía profundamente modificado, porque "las ciencias tienen historias complejas en la constitución de mundos imaginativos y de cuerpos concretos en las sociedades" (1990: 6. Traducción propia). De esta forma, Haraway en 1990 procuraba disputar las lecturas de los textos de la Ciencia. Para este nuevo libro vuelve a recurrir a aquella figuración, que ha ido puliendo a lo largo de los años. Primero nos hace una lista, SF es "ciencia ficción [science fiction], fabulación especulativa [speculative fabulation], figuras de cuerdas [string figures], feminismo especulativo [speculative feminism], hechos científicos [scientific facts] y hasta ahora [so far]" (Haraway, 2019: 21). Las ciencias, los feminismos y las ficciones se necesitan y pueden conformar patrones que nos ayuden a pensarnos y anudarnos unes a otres. Pero como las listas nunca alcanzan la autora hace tres aclaraciones sobre la noción. Por un lado, SF es una práctica de rastreo, tal como el rastreo que hacemos las feministas del sur en la búsqueda de nuestras genealogías: historias siempre fragmentadas, parciales, ocultas y ocultadas. Por otro lado, SF no es sólo un método sino también "la cosa en cuestión, el patrón y ensamblaje que requiere respuesta, la cosa que no es una misma pero con la que una tiene que seguir andando" (Haraway, 2019: 22). 
Finalmente, SF es una práctica que nuestras ancestras feministas nos han enseñado, "es pasar y recibir, hacer y deshacer, coger hilos y soltarlos" (Haraway, 2019: 22). SF entonces es una práctica, pero también un proceso, es la posibilidad misma de la continuidad de la vida y la muerte en nuestro mundo.

Pero en el Antropoceno ${ }^{2}$ ¿es posible seguir hablando de continuidad, de devenir-con, de emancipación, de vivir y morir de maneras más amables? Haraway nos marcará que pensar nuestra época desde términos como Antropoceno, Capitaloceno y/o Plantacionoceno nos lleva demasiado rápido al derrotismo. "A solas, desde nuestras maneras distintivas de experiencia y pericia, sabemos a la vez demasiado y demasiado poco, y así sucumbimos a la desesperación o la esperanza" (Haraway, 2019: 24). La propuesta de la autora desestimará la fe en las soluciones mágicas (seculares o religiosas) y el cinismo de pensar que todo ha acabado. No van a 'salvarnos' ni las vacunas, ni las políticas de indiferencia; pero tampoco les humanes vamos a 'salvar' a la Tierra. Y es que seguir con el problema implica tener la respons-habilidad ${ }^{3}$ de comprender que "una inmensa e irreversible destrucción está realmente en marcha" (Haraway, 2019: 157), pero que "contrariamente a los dramas dominantes [...] los seres humanos no somos los únicos actores importantes" (Haraway, 2019: 95).

Por todo esto, a lo largo del libro Haraway va pasándonos algunos patrones SF donde conjuga: científiques (estudioses de la ciencia, la antropología y la narración); teorías sobre las relaciones entre ecología, evolución y biología del desarrollo; proyectos colaborativos de arte-ciencia donde humanes y no humanes (tecnológicos y orgánicos) buscan maneras de trabajar en conjunto (en relaciones asimétricas de poder); extractivismo, pueblos indígenas contemporáneos y ovejas; estrógenos y su socia de investigación Cayene (la perra que acompaña a la autora); hormigas y semillas de acacia; bichos que se vuelven mutuamente capaces en relaciones inesperadas; entre muchas otras historias/teorías. El capítulo final es el primer intento de la autora de escribir ciencia ficción, un texto realizado colaborativamente con director de cine Fabrizio Terranova y la filósofa Vinciane Despret, que relata la vida de cinco generaciones de alianzas simbióticas entre humanes y mariposas.

\footnotetext{
${ }^{2}$ Nuevo término geológico para referirse a nuestra era que vendría a reemplazar a Holoceno.

${ }^{3}$ Juego de palabras en inglés: response-ability, que significa responsabilidad y habilidad para dar respuesta
} 
Haraway es muy consciente de los peligros a los que están expuestos "los refugiados" de cualquier especie, y sabe que "al borde de la extinción" o "el colapso del sistema" no son ni metáforas, ni películas de suspenso (2019: 157). Justamente por eso, nos va narrando las potencias y poderes de las historias y prácticas multiespecies, modos imaginados y reales de vivir y morir con-otres (humanes y no humanes) en esta tierra dañada que ella llama Chthuluceno. Es decir, el espaciotiempo real, que nada tiene que ver con el Cthulhu aquel monstruo racista y misógino imaginado por Lovecraft, pero sí tiene mucho que ver con la simpoiesis. Simpoiesis significa "generar-con", supera el modelo autopoiético del Antropoceno, porque "[n]ada se hace a sí mismo" y "los terrícolas nunca están solos" (Haraway, 2019: 99). Ya nos había preguntado provocativamente Haraway en el Manifiesto Ciborg. El sueño irónico de un lenguaje común para las mujeres en el circuito integrado "¿Por qué nuestros cuerpos deberían terminarse en la piel [...]?" (Haraway, 1995: 305). Esta frase que fue entendida 'hacia afuera' es decir, considerando todas las prótesis que nos conforman como humanes con-otres no humanes (orgánicos y tecnológicos), también puede ser entendida 'hacia adentro', considerando las innumerables bacterias que viven con-nosotres y hacen posible nuestra vida. Sucede que ningún "bicho" precede a sus relacionalidades, sino que "se generan mutuamente a través de una involución semítico-material, a partir de seres de enredos anteriores" (Haraway, 2019: 100-101). Por ello, el subtítulo del libro propone generar parentesco, que no tiene relación con los "lazos de sangre', 'linajes' o 'genes'; sino con "unir fuerzas para reconstituir refugios, para hacer posible una recuperación y recomposición biológica-cultural-política-tecnológica sólida y parcial, que debe incluir el luto por las pérdidas irreversibles" (Haraway, 2019: 156-157).

De todas maneras, interesa destacar que el parentesco y las conexiones están siempre situadas: "[n]adie vive en todas partes, todo el mundo vive en algún lugar. Nada está conectado a todo, todo está conectado a algo" (Haraway, 2019: 61). Aquí sigue presente otra de las premisas que la autora sostiene desde hace mucho tiempo, la de la situacionalidad de los cuerpos, siempre complejos, contradictorios, estructurantes y estructurados (Haraway, 1995).

Brevemente he tratado de mostrar la importancia que tiene leer este libro hoy, porque hoy es el momento de recolectar la basura, el exterminio,la tristeza, los despojos y los duelos para hacer compost, para cultivar una justicia multiespecies. Lo hayamos pedido o no el patrón SF está en nuestras manos, de qué hilos queremos tirar, cuáles deseamos no seguir, con qué seres queremos hacerlo y de qué maneras son las preguntas que Haraway nos invita a hacernos: "Pensar debemos, debemos pensar" (Stengers y Despret en Haraway, 2019: 59). 


\section{Referencias bibliográficas}

HARAWAY, Donna. Ciencia, cyborgs y mujeres. La reinvención de la naturaleza. Madrid: Cátedra, 1995.

HARAWAY, Donna. Primate Visions: Gender, Race, and Nature in the World of Modern Science. Londres: Routledge, 1990.

HARAWAY, Donna. Seguir con el problema: Generar parentesco en el Chthulceno. Bilbao: Consonni, 2019 